\title{
Vitamin D and musculoskeletal health, cardiovascular disease, autoimmunity and cancer: recommendations for clinical practice
}

Jean-Claude Souberbielle ${ }^{\mathrm{a}}$; Jean-Jacques Body ${ }^{\mathrm{b}}$; Joan M. Lappe ${ }^{\mathrm{c}}$; Mario Plebani ${ }^{\mathrm{d}}$; Yehuda Shoenfeld ${ }^{\mathrm{e}}$; Thomas J. Wang ${ }^{\mathrm{f}}$; Heike A. Bischoff-Ferrari ${ }^{\mathrm{g}}$; Etienne Cavalier ${ }^{\mathrm{h}}$; Peter R. Ebeling $^{\mathrm{i}}$; Patrice Fardellone ${ }^{\mathrm{j}}$; Sara Gandini ${ }^{\mathrm{k}}$; Damien Gruson ${ }^{1}$; Alain P. Guérin ${ }^{\mathrm{m}}$; Lene Heickendorff $^{\mathrm{n}}$; Bruce W. Hollis ${ }^{\mathrm{o}}$; Sofia Ish-Shalom ${ }^{\mathrm{p}}$; Guillaume Jean ${ }^{\mathrm{q}}$; Philipp von Landenberg ${ }^{\mathrm{r}}$; Alvaro Largura ${ }^{\mathrm{s}}$; Tomas Olsson ${ }^{\mathrm{t}}$; Charles Pierrot-Deseilligny ${ }^{\mathrm{u}}$; Stefan Pilz ${ }^{\mathrm{v}}$; Angela Tincani $^{\mathrm{w}}$; Andre Valcour ${ }^{\mathrm{x}}$; Armin Zittermann ${ }^{\mathrm{y}}$

\section{Author affiliations:}

${ }^{\mathrm{a}}$ Laboratoire de Physiologie, CHU Necker, Paris, France; ${ }^{\mathrm{b}}$ Department of Medicine, CHU Brugmann, Université Libre de Bruxelles, Brussels, Belgium; ${ }^{c}$ Internal Medicine, Creighton University, Omaha NE, USA; ${ }^{\mathrm{d}}$ Laboratory Medicine, University of Padova, Leonardo Foundation, Abano Terme General Hospital, Italy; ' Department of Medicine B', Zabludowizc center for autoimmune diseases, Sheba Medical Center, Tel-Hasomer, Sackler Faculty of Medicine, Tel-Aviv University, Israel; ${ }^{\mathrm{f}}$ Division of Cardiology, Massachusetts General Hospital, Harvard Medical School, Boston, USA; ${ }^{\mathrm{g}}$ Centre on Aging and Mobility, University of Zurich; Dept. of Rheumatology and Institute of Physical Medicine, University Hospital, Zurich , Switzerland; ${ }^{\mathrm{h}}$ Department of Clinical Chemistry, University of Liège, CHU de Liège, Liège, Belgium; ${ }^{i}$ Medicine (RMH/WH), The University of Melbourne, Footscray, Victoria 3011, Australia; ${ }^{\mathrm{j}}$ Rheumatology, CHU Amiens, INSERM ERI 12, Amiens, France; ${ }^{\mathrm{k}}$ Division of Epidemiology and Biostatistics, European Institute of Oncology, Milan, Italy; ${ }^{1}$ Department of Laboratory Medicine, Cliniques Universitaires St-Luc, Brussels, Belgium; ${ }^{\mathrm{m}}$ Nephrology, Centre hospitalier Manhes, Fleury Mérogis, France; ${ }^{\mathrm{n}}$ Department of Clinical Chemistry, Aarhus University Hospital, Aarhus, Denmark; ${ }^{\circ}$ Pediatrics, Medical University of 
South Carolina, Charleston, SC, USA; ${ }^{\mathrm{p}}$ Bone and Mineral Metabolism Unit, Rambam Health Care Campus, Technion Faculty of Medicine, Haifa, Israel; ${ }^{\mathrm{q}}$ Dialysis, Centre de Rein Artificiel, Tassin, France; ${ }^{r}$ Solothurner Spitäler AG, Institut für Labormedizin (IFLM), Olten, Switzerland; ${ }^{\mathrm{S}}$ Clinical Chemistry, Alvaro Center of Analysis and Clinical Research /DASA, Cascavel, Brazil; ${ }^{\mathrm{t}}$ Neuroimmunology Unit, Center for Molecular Medicine, Department of

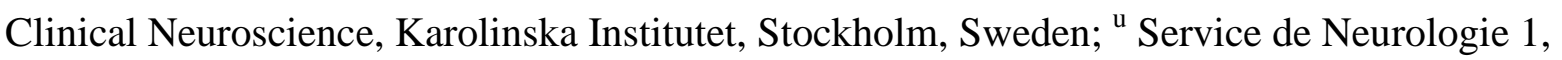
Hôpital de la Salpêtrière, Paris, France; ${ }^{\vee}$ Department of Internal Medicine, Division of Endocrinology and Nuclear Medicine, Medical University of Graz, Graz, Austria; ${ }^{\text {w }}$ Rheumatology and Clinical Immunology, Spedali Civili and University of Brescia, Brescia, Italy; ${ }^{\mathrm{x}}$ Center for Esoteric Testing, Laboratory Corporation of America, Burlington, NC, USA; ${ }^{y}$ Clinic for Thoracic and Cardiovascular Surgery, Heart Center North Rhine-

Westphalia, Bad Oeynhausen, Germany

\section{Corresponding author:}

Prof. Jean-Claude Souberbielle

CHU Necker, Laboratoire de Physiologie

149 rue de Sèvres

75015 Paris,

France

Phone: +33144381743

Fax: +33144495058

E-mail: jean-claude.souberbielle@nck.aphp.fr

\section{Financial disclosure:}

None reported: MP, YS, EC, PF, SG, APG, LH, GJ, PvL, AL, TO, CP-D, AT, AZ

No other than consultancy fees from DiaSorin for participating in the Summit Meeting: JJB, PRE, DG 
Received lecture fees from DiaSorin: JCS, SP

DiaSorin Advisory Panel for Vitamin D: JML, TJW, AV

Academic Consultant to DiaSorin Corp: BH

Received consulting and lecture fees from Aventis,DiaSorin, CTS, Eli - Lilly, MSD,

Meditec, and received grant support from , Eli - Lilly (1996, 2000, 2004, 2005-present),

MSD ( 2008 -present), Novartis (2003, 2008), Transpharma (2007): SI-S

Lecture and consulting fees from MSD, Amgen, Novartis, Roche, DSM, Nestle: HABF 


\begin{abstract}
Background: There is increasing evidence that, in addition to the well-known effects on musculoskeletal health, vitamin D status may be related to a number of non-skeletal diseases. An international expert panel formulated recommendations on vitamin D for clinical practice, taking into consideration the best evidence available based on published literature today. In addition, where data were limited to smaller clinical trials or epidemiologic studies, the panel made expert-opinion based recommendations.
\end{abstract}

Methods: Twenty-five experts from various disciplines (classical clinical applications, cardiology, autoimmunity, and cancer) established draft recommendations during a 2-day meeting. Thereafter, representatives of all disciplines refined the recommendations and related texts, subsequently reviewed by all panelists. For all recommendations, panelists expressed the extent of agreement using a 5-point scale.

Results and conclusion: Recommendations were restricted to clinical practice and concern adult patients with or at risk for fractures, falls, cardiovascular or autoimmune diseases, and cancer. The panel reached substantial agreement about the need for vitamin D supplementation in specific groups of patients in these clinical areas and the need for assessing their 25-hydroxyvitamin D $(25(\mathrm{OH}) \mathrm{D})$ serum levels for optimal clinical care. A target range of at least 30 to $40 \mathrm{ng} / \mathrm{mL}$ was recommended. As response to treatment varies by environmental factors and starting levels of $25(\mathrm{OH}) \mathrm{D}$, testing may be warranted after at least 3 months of supplementation. An assay measuring both $25(\mathrm{OH}) \mathrm{D}_{2}$ and $25(\mathrm{OH}) \mathrm{D}_{3}$ is recommended. Dark-skinned or veiled individuals not exposed much to the sun, elderly and institutionalized individuals may be supplemented (800 IU/day) without baseline testing.

Key-words: vitamin D, supplementation, 25(OH)D, testing, recommendations 


\section{Take home messages}

- The $25(\mathrm{OH}) \mathrm{D}$ level in specific groups of patients with or at risk for musculoskeletal health problems, cardiovascular disease, autoimmune disease and cancer should be above $30 \mathrm{ng} / \mathrm{mL}$ for optimal health benefit

- The expert panel agreed on an upper safety limit for 25(OH)D of $100 \mathrm{ng} / \mathrm{mL}$

- In these patients, a large correcting dose can be proposed initially, followed by a maintenance treatment of $800 \mathrm{IU} /$ day (or equivalent with intermittent dosing), which can be increased if levels remain insufficient during monitoring

- Supplementation (800 IU/day) without baseline testing is recommended in darkskinned or veiled individuals not exposed much to the sun, elderly and institutionalized individuals

- The interval between starting vitamin D supplementation and measuring/monitoring the $25(\mathrm{OH}) \mathrm{D}$ level should at least be 3 months

- The expert panel recommends to use an assay measuring both $25(\mathrm{OH}) \mathrm{D}_{2}$ and $25(\mathrm{OH}) \mathrm{D}_{3}$ 


\section{Introduction}

\subsection{Background and aim of the paper}

Once thought to have consequences only for bone health, vitamin D deficiency has been associated with a large number of conditions such as cancer, autoimmune disease, and cardiovascular disease. A large part of the population does not meet vitamin D requirements because vitamin D is mainly synthesized when the skin is exposed to ultraviolet (UV) B radiation and contemporary life is associated with reduced sun exposure (we expose less than $5 \%$ of our skin to the sun) and use of UVB-blocking sunscreens [1]. Dark-skinned individuals require more sun exposure to have the same vitamin D production as people with less skin pigmentation, and the same is true for older versus younger individuals[2]. Dietary sources of vitamin $\mathrm{D}_{3}$ (cholecalciferol) are few and only significant in oily fish. Vitamin $\mathrm{D}_{2}$ (ergocalciferol), the plant/mushroom form of vitamin D, is almost absent in the diet. Supplementation with vitamin $\mathrm{D}$ can be done either with vitamin $\mathrm{D}_{2}$ or vitamin $\mathrm{D}_{3}$ but availability of these two forms greatly differs between countries. The optimal serum level of 25-hydroxyvitamin $\mathrm{D}(25(\mathrm{OH}) \mathrm{D})$-the primary circulating form of vitamin $\mathrm{D}$ - needed for optimal health is unknown. However, a recent benefit-risk assessment of vitamin D suggested that it may be similar or possibly higher than needed for optimal bone health and calcium metabolism[3].

The abundance of publications on vitamin D (PubMed search: 2,844 in 2000-2001 increasing to 4,635 in 2008-2009), differing in level of evidence and consequences for clinical practice, hinders the physician in assessing the importance of vitamin D status for a specific patient. Therefore, a 2-day Vitamin D Summit Meeting was held on 7-8 November 2009 in Paris, with the goal of translating current evidence from clinical, experimental and epidemiological studies into recommendations for everyday clinical practice. The recommendations are intended to be used in clinical practice and concern adult patients with, or individuals at risk 
for, classical applications of vitamin D such as osteoporosis, chronic kidney disease (CKD), and endocrinopathies. On the other hand the recommendations apply to adult patients with, or individuals at least 18 years old at risk for, diseases in which the role of vitamin $\mathrm{D}$ is emerging such as cardiovascular and autoimmune diseases and cancer. Therefore, a multidisciplinary group of 25 experts, from 12 different countries, addressed the following questions with regard to the described population:

- Who should be tested for vitamin D deficiency?

- What is the recommended range of serum $25(\mathrm{OH}) \mathrm{D}$ ?

- Who should be supplemented?

- When should the testing be performed?

This perspective differs from, and could result in another set of standards than policy documents intended for the community at large (e.g. Institute of Medicine[4] and Standing Committee of European Doctors[5]). Until the results of long-term large scale randomized controlled trials (RCTs) in the emerging fields are available, the recommendations presented in this paper should not be extrapolated to the general healthy population.

\subsection{Panel methodology}

The chairpersons of the meeting (MP, JCS, JJB, JL, YS, TW), all experts in the field, defined the format of the meeting and warranted that the participants consisted of experts on vitamin $\mathrm{D}$ in different clinical specialties. The meeting started with a plenary session in which the state of the art was outlined from different perspectives and disciplines. Afterwards, the most important literature referring to a disease area was discussed in group sessions per specialty and translated into recommendations for each specialty. The recommendations were then presented and discussed during a plenary session. 
The paper, consisting of a brief summary of the most important evidence and recommendations for clinical practice, based on the literature review and the experience of the authors, was drafted by the chairpersons. The draft was reviewed by all panel members and a scoring system was applied to measure agreement for each of the recommendations.

\section{Classical and non-classical effects of vitamin D}

\subsection{Classical clinical effects of vitamin D}

Vitamin D has an impact on bone density and bone quality. In addition, by increasing muscle strength, adequate vitamin D status reduces the risk of falling in older individuals. Therefore, vitamin D has a dual benefit for prevention of fractures in the elderly, a benefit on bone density and muscle strength. To determine the anti-fracture efficacy of oral vitamin D supplementation in individuals $\geq 65$ years old, Bischoff-Ferrari et al. did a meta-analysis of 12 double-blind RCTs for non-vertebral fractures $(\mathrm{n}=42,279)$ and 8 RCTs for hip fractures $(\mathrm{n}=$ 40,886)[6]. The pooled relative risk (RR) was 0.86 (95\% CI, 0.77-0.96) for prevention of nonvertebral fractures and 0.91 (95\% CI, 0.78-1.05) for the prevention of hip fractures. However, there was a significant heterogeneity for both endpoints. Factors explaining the heterogeneity were 'dose' and 'achieved blood 25(OH)D levels'. When looking at the trials with a high (482-770 IU/day or 12.0-19.25 $\mu \mathrm{g} /$ day) received dose (i.e. dose adjusted for adherence) of vitamin D, non-vertebral fractures were reduced by $20 \%$ and hip fractures by $18 \%$, whereas doses $<400$ IU/day did not show any effect and fracture reduction was only achieved in trial that achieved 25(OH)D levels of at least 30 to $40 \mathrm{ng} / \mathrm{ml}$.

Furthermore, vitamin D has been shown to improve muscle performance and reduce the risk of falling in community-dwelling as well as institutionalized elderly. A meta-analysis including 8 double-blind RCTs $(n=2,426)$ demonstrated that falling was significantly reduced by $13 \%$ in vitamin D supplemented individuals compared with those receiving 
calcium or placebo[7]. Again, a significant heterogeneity by dose and achieved 25(OH)D levels was observed. Higher dose supplemental vitamin D (700-1000 IU/day) reduced the relative risk of falls by $19 \%$.

This translates to an achieved serum 25(OH)D level of at least $24 \mathrm{ng} / \mathrm{mL}(60 \mathrm{nmol} / \mathrm{L}$, conversion factor 2.496) for anti-fall efficacy and at least $30 \mathrm{ng} / \mathrm{mL}$ for anti-fracture efficacy[8].

Further, both fall and fracture prevention continued to increase with higher achieved 25(OH)D levels up to $44 \mathrm{ng} / \mathrm{mL}[3]$.

Another group of patients, in which the role of vitamin D in maintaining calcium homeostasis is very important, comprises those with CKD and/or on dialysis. Studies in these patients have shown that they commonly suffer from vitamin D deficiency[9-11]. Low 25(OH)D levels have been associated with atherosclerosis and endothelial dysfunction in patients with end stage renal disease and on hemodialysis[12] and increased 90-day mortality in patients on hemodialysis [11]. Furthermore, in patients with CKD 2-5, the 25(OH)D level is an independent predictor of disease progression and mortality[10;13]. Jean et al. prospectively showed that vitamin D supplementation decreased serum PTH without increasing phosphatemia or calcemia in dialysis patients[9].

\subsection{Effects of vitamin D in non-classical clinical fields}

While the evidence on bone and muscle health is based on RCTs, the evidence on other disease areas is of a lower level. Trials are small to moderate sized and the outcomes of interest are often secondary outcomes. A meta-analysis of 18 RCTs including 57,311 individuals concluded that vitamin D supplementation was associated with a decrease in total 
mortality (RR 0.93 ; 95\% CI, 0.77-0.96 compared to the control group)[14]. A large body of experimental and epidemiologic data is available, and summarized below.

\subsubsection{Effects of vitamin D on the cardiac system}

A low level of $25(\mathrm{OH}) \mathrm{D}$ appears to be an independent risk factor for cardiovascular events, although a causal relationship has yet to be supported by large interventional trials. The evidence on the link between vitamin D deficiency and myocardial diseases has recently been reviewed[15]. In addition to possible direct effects due to the presence of the vitamin D receptor (VDR) and of the 1-alpha hydroxylase enzyme in cardiomyocytes and other cells of the cardiovascular system[16], vitamin D has significant effects on several cardiovascular risk factors. Studies, ranging from animal trials to RCTs, have shown that vitamin D reduces inflammation[17], controls several matrix metalloproteinases (MMPs) involved in vascular calcification[18], improves endothelial function[19], controls the secretion of insulin and improves insulin sensitivity[20;21], and decreases parathyroid hormone (PTH) secretion[22]. Furthermore, as reviewed recently by Pilz et al.,[23] vitamin D status has been linked to arterial hypertension[24].

In a small RCT, 8 weeks of supplementation with vitamin $\mathrm{D}_{3}(800 \mathrm{UI} /$ day $)$ and calcium was more effective in reducing systolic blood pressure than calcium alone[25]. In the Women's Health Initiative, an RCT including 36,282 postmenopausal women, vitamin $\mathrm{D}_{3}$ plus calcium supplementation did not reduce blood pressure, nor the risk of developing hypertension over seven years of follow-up; however in this trial supplementation consisted only of 400 IU/day and adherence to supplementation was only around $60 \%[26]$. A recent meta-analysis of 8 RCTs in patients with a mean baseline blood pressure above 140/90 mmHg concluded that vitamin D reduces blood pressure modestly but significantly in hypertensive patients[27]. Another RCT in 200 healthy overweight individuals in a weight-reduction program showed 
that 12 months of vitamin D supplementation $(83 \mu \mathrm{g} / \mathrm{day})$ resulted in a significant reduction of PTH, triglycerides and TNF-alpha compared to placebo, however the LDL-cholesterol concentration increased in the supplementation group[28].

Observational studies consistently indicate that $25(\mathrm{OH}) \mathrm{D}$ levels less than $15 \mathrm{ng} / \mathrm{mL}$ are associated with excess risk of cardiovascular events, when compared with levels $>30-40$ ng/mL. A nested case-control study in 18,225 men in the Health Professionals Follow-up Study (men aged 40-75, free of diagnosed cardiovascular disease at blood collection) showed that men with a $25(\mathrm{OH}) \mathrm{D}$ level $\leq 15 \mathrm{ng} / \mathrm{mL}$ had an increased risk for myocardial infarction (MI) relatively to men with a $25(\mathrm{OH}) \mathrm{D}$ level $\geq 30 \mathrm{ng} / \mathrm{mL}$ (RR $2.42 ; 95 \% \mathrm{CI}, 1.35-3.84)[29]$. Even men with a 25(OH)D level 22.6-29.9 ng/mL had an increased risk ( RR 1.60; 95\% CI, 1.10-2.32) compared with those with a $25(\mathrm{OH}) \mathrm{D}$ level $\geq 30 \mathrm{ng} / \mathrm{mL}$. In the Framingham Offspring cohort study, the $25(\mathrm{OH}) \mathrm{D}$ level was measured in 1,739 participants without prior heart disease[30]. At a mean follow-up of 5.4 years, among those with hypertension, there was a two-fold increase in the risk of cardiovascular events for the participants with a $25(\mathrm{OH}) \mathrm{D}$ level $<15 \mathrm{ng} / \mathrm{mL}$ compared to those with a $25(\mathrm{OH}) \mathrm{D}$ level $\geq 15 \mathrm{ng} / \mathrm{mL}$. The LUdwigshafen RIsk and Cardiovascular health (LURIC) study, a prospective cohort comprising 3,300 patients referred to coronary angiography and followed for 7.7 years, demonstrated a strong association between vitamin D status and several cardiovascular outcomes, such as cardiovascular mortality[31], stroke[32], heart failure and sudden cardiac death with the lowest risk among those with the highest 25(OH)D level[33].

\subsubsection{Vitamin D and the immune system}

Many autoimmune diseases such as type 1 diabetes mellitus or multiple sclerosis (MS) are more frequent in countries with less sunshine[34]. Studies using animal models of several autoimmune diseases have identified vitamin D as a potential modulator of differentiation, 
proliferation and secretion processes in autoimmune reaction. Supplementation in humans may be preventive in a number of autoimmune disorders[35].

A Finnish birth-cohort study, including $>10,000$ children born in 1966, showed that vitamin D supplementation during the first year of life (2,000 IU/day) was associated with a risk reduction of $78 \%$ for developing type 1 diabetes (followed-up until end 1997) compared to no supplementation or lower doses[36]. A few studies indicate that treatment with vitamin D could be beneficial as well in reducing the risk of developing MS and diminishing exacerbations of MS in affected patients[37;38]. In addition, a small 28-week trial in which MS patients received 28,000 to 280,000 IU/week provided evidence that high-dose vitamin D supplementation is safe in these patients[39]. Although contradictory data exist concerning supplementation benefits in rheumatoid arthritis (RA) and systemic lupus erythematosus (SLE), an association between low levels of 25(OH)D and SLE disease activity[40] or RA disease activity[41] has recently been shown. Furthermore, an inverse association between higher intake of vitamin D and risk of RA was demonstrated in the Iowa Women's Health Study[42].

\subsubsection{Vitamin D and oncology}

Many experimental data show that calcitriol stimulates apoptosis and differentiation and inhibits angiogenesis and proliferation in tumour cells[43]. Numerous association studies suggest that serum $25(\mathrm{OH}) \mathrm{D}$ levels are inversely associated with the risk of many types of cancer. Further, in some studies of patients with cancer, an association between low $25(\mathrm{OH}) \mathrm{D}$ levels and poor prognosis has been observed[44;45]. A meta-analysis of available studies indicated that there is a trend for lower incidence of colorectal carcinoma and adenoma with 25(OH)D levels $>20 \mathrm{ng} / \mathrm{ml}$ in dose-response association (International Agency for Research and Cancer (IARC) report 2008, conducted for WHO)[46]. For breast cancer, a pooled 
analysis of 2 studies with 880 cases and 880 controls demonstrated that individuals with serum 25(OHD of approximately $52 \mathrm{ng} / \mathrm{mL}$ had $50 \%$ lower risk of breast cancer than those with levels $<13 \mathrm{ng} / \mathrm{mL}$ [47]. In addition, a large case-control study on 1,394 post-menopausal breast cancer patients and 1,365 controls confirmed that the $25(\mathrm{OH}) \mathrm{D}$ level was significantly associated with lower breast cancer risk, particularly at levels above $20 \mathrm{ng} / \mathrm{mL}$ [48]. Based on the IARC report 2008, which included all the available observational studies on breast cancer, a decreased risk was associated with higher serum $25(\mathrm{OH}) \mathrm{D}$ in case-controls studies. However, results from prospective studies only are more heterogeneous and did not support a significant association between vitamin D status and breast cancer[46].

There have been no clinical trials with cancer incidence or mortality as a primary outcome to support causality between vitamin D status and cancer. However, one population based RCT found that calcium plus vitamin D supplementation decreased cancer incidence as a secondary outcome. In that study ( $\mathrm{n}=1179$ healthy postmenopausal women aged $>55$ year), the level of 25(OH)D at baseline was $29 \mathrm{ng} / \mathrm{mL}$. Supplementation with $1100 \mathrm{IU} /$ day increased serum $25(\mathrm{OH}) \mathrm{D}$ to $38 \mathrm{ng} / \mathrm{mL}$. After four years of treatment, the supplemented group had a $60 \%$ lower risk of developing cancer than the placebo group[49]. In another randomized trial, the Women's Health Initiative, no effect of calcium and 400 IU vitamin D/day was found on the incidence of colorectal or breast cancer, which were secondary outcomes[50;51]. However, the dose of $400 \mathrm{IU}$ used in that trial may have been inadequate to raise $25(\mathrm{OH}) \mathrm{D}$ blood levels significantly, particularly after factoring in adherence levels.

\section{Recommendations of the expert panel}

The authors acknowledged the lack of adequate RCT data in the non-musculoskeletal disease areas and the fact that most RCTs were performed in older individuals, but they formulated recommendations based on the available evidence, risk-benefit considerations and clinical 
experience. All recommendations were individually scored using an agreement index ranging from 1 (not agree at all) to 5 (fully agree). The mean score is presented in the text next to each recommendation.

\subsection{Who should be tested for its serum $25(\mathrm{OH})$ D level?}

The authors distinguished between 2 groups of individuals seen in the clinic:

a. those who should have a $25(\mathrm{OH}) \mathrm{D}$ test (summarized in Table 1)

b. those who may be supplemented without a test at baseline because they are very likely to have low levels of $25(\mathrm{OH}) \mathrm{D}$ (further explained in 3.3 )

In addition to the individuals in whom testing is recommended (Table 1), testing could be considered in individuals at risk for hypertension or other cardiovascular diseases (agreement score 4.1).

\subsection{Recommended range of $25(\mathrm{OH}) \mathrm{D}$}

Based upon the presented evidence, a $25(\mathrm{OH}) \mathrm{D}$ level of $30-44 \mathrm{ng} / \mathrm{mL}$ provides optimal benefits for outcomes in musculoskeletal and cardiovascular health and cancer[3].

Therefore, the panel recommended that the $25(\mathrm{OH}) \mathrm{D}$ level in individuals with or at risk for musculoskeletal health problems, cardiovascular disease, autoimmune disease and cancer, as indicated in Table 1, should be above $30 \mathrm{ng} / \mathrm{mL}$ (agreement score 4.8). It was emphasized that the measurement uncertainty related to the $25(\mathrm{OH}) \mathrm{D}$ assay must be taken into account (as for any biological parameter). According to recent reports, choosing a threshold of $30 \mathrm{ng} / \mathrm{mL}$ will ensure that the patient has a true concentration that is $>20$ $\mathrm{ng} / \mathrm{mL}[52 ; 53]$. The experts discussing the classical applications emphasized that this lower limit of $30 \mathrm{ng} / \mathrm{mL}$ is especially important for patients with secondary causes of osteoporosis such as primary hyperparathyroidism, as well as for patients with renal disease stage 3-5D (including thus dialysis patients), as stated in the most recent guidelines[54]. The effects of 
seasonal variation should be taken into account and an attempt should be made to maintain the minimum level in all seasons.

As vitamin D may be toxic at extremely high doses, the panel also considered the safety of the higher 25(OH)D levels and proposed an upper safety limit of $100 \mathrm{ng} / \mathrm{mL}$ (agreement score 4. 6). Sunbathing can produce vitamin $\mathrm{D}$ doses equivalent to an oral vitamin $\mathrm{D}$ intake of up to 20,000 IU per day and in healthy subjects who have spent prolonged periods in a sunny environment, measured $25(\mathrm{OH}) \mathrm{D}$ concentrations rarely exceed $100 \mathrm{ng} / \mathrm{mL}$, suggesting that this level may be considered as a safe upper limit for serum 25(OH)D levels[55-57]. Most international authorities consider a vitamin D intake of 2,000 IU daily as absolutely safe, although a recent review found that even doses of up to 10,000 IU per day supplemented over several months did not lead to any adverse events[58].

Furthermore, a benefit-risk assessment of Vitamin D supplementation reports that hypercalcemia caused by excess vitamin D in generally healthy adults has been observed only if daily intake was > 100,000 IU or if the $25(\mathrm{OH}) \mathrm{D}$ level exceeded $100 \mathrm{ng} / \mathrm{mL}[3]$. However, Bischoff-Ferrari pointed out that there are currently no data to support that levels above 50 $\mathrm{ng} / \mathrm{mL}$ would result in additional benefits than $30-44 \mathrm{ng} / \mathrm{mL}$. Therefore, $100 \mathrm{ng} / \mathrm{mL}$ should be considered as a safety limit but not as an upper limit to target in clinical practice. At the Necker Hospital, to present an example from clinical practice, the range of vitamin D indicated on the lab report is $30-80 \mathrm{ng} / \mathrm{mL}$, however, the dose of vitamin D supplementation is slightly reduced when measuring levels of $70-80 \mathrm{ng} / \mathrm{mL}$. Although such levels are considered as absolutely safe, it is not the level targeted to obtain optimal health outcomes. The position of all individual participants regarding the range for serum $25(\mathrm{OH}) \mathrm{D}$ levels is indicated in Appendix 1, and a summary is presented in Table 2.

\subsection{Who should be supplemented, which supplements, and which doses should be used?}


According to a rule of thumb, an intake of 1,000 IU vitamin D/day results in an increase of approximately $10 \mathrm{ng} / \mathrm{mL}$ in 25(OH)D, although individual responses are variable[59]. Supplementation without baseline $25(\mathrm{OH}) \mathrm{D}$ measurement is recommended for dark-skinned or veiled subjects not exposed much to the sun (agreement score: 4.5), individuals without musculoskeletal health problems, cardiovascular disease, autoimmune disease and cancer $\geq$ 65 years old (agreement score: 4.2) and institutionalized subjects (agreement score: 4.4). In these individuals a dose of $800 \mathrm{IU} /$ day (the standard dose of most RCTs) or its equivalent with an intermittent dosing regimen (i.e 100,000 IU every 3 months) is recommended (agreement score: 4.2). Although daily dosages seem more physiologic, several studies have reported that a dose of vitamin $\mathrm{D}_{3}$ given intermittently (i.e monthly), has approximately similar effects on $25(\mathrm{OH}) \mathrm{D}$ concentration as the same cumulative dose given daily for the same period[60]. Recently, an RCT showed that administration of a single annual high dose (500,000 IU) of vitamin D could result in adverse outcomes which were suggested to be related to the dosing regimen[61]. Therefore daily, weekly or monthly strategies may be preferred.

Measurement of $25(\mathrm{OH}) \mathrm{D}$ and subsequent supplementation if $<30 \mathrm{ng} / \mathrm{mL}$ is recommended for all other individuals listed in Table 1 (agreement score: 4.8). In these subjects, a large correcting dose can be proposed initially (e.g. 50,000 IU capsule of vitamin $\mathrm{D}_{2}$ once a week for 8 weeks as proposed in[1]), followed by a maintenance treatment. For this second phase, an initial dose of $800 \mathrm{IU} /$ day is recommended (or its equivalent, with intermittent dosing), checking compliance and possibly increasing the dose if during monitoring the level remains insufficient (agreement score: 4.5). This is especially important for specific disease conditions that are associated with malabsorption syndromes (e.g. celiac disease). 
The panel recognized that, due to important disparity among countries regarding the available forms and dosages of vitamin $\mathrm{D}$, it is difficult to recommend a specific treatment regimen. According to what is available in a given country, the choice of a given supplementation regimen may depend on the preference of the patient. Observance of adherence to supplementation is essential. In countries where both vitamin $\mathrm{D}_{2}$ and vitamin $\mathrm{D}_{3}$ are available, supplementation with $\mathrm{D}_{3}$ is to be preferred, as it avoids problems with differences in 25(OH)D assay specificity (agreement score: 4.7). It must be mentioned however that vitamin $D_{2}$ and vitamin $D_{3}$ seem to have similar effects on $25(\mathrm{OH}) \mathrm{D}$ levels when given as daily doses[62]. By contrast, supplementation using an intermittent regimen is much more reliable for vitamin $\mathrm{D}_{3}$ than it is for vitamin $\mathrm{D}_{2}$, as vitamin $\mathrm{D}_{3}$ maintains serum $25(\mathrm{OH}) \mathrm{D}$ concentration for a longer period[63;64]. The need for the addition of calcium to vitamin D is dependent on the patient's diet. Strict vegetarians may prefer supplementation with vitamin $\mathrm{D}_{2}$ (plant origin) instead of $\mathrm{D}_{3}$ (animal origin). Similarly, for religious reasons, some patients may refuse to take a vitamin D supplement that is diluted in an alcoholic solution.

\subsection{When should the testing be performed and how often should the monitoring occur?}

As mentioned above, if supplementation is to be considered, baseline measurement should be performed with the exception of dark-skinned or veiled individuals not exposed much to the sun, individuals $\geq 65$ years without musculoskeletal health problems, cardiovascular disease, autoimmune disease or cancer, and institutionalized subjects. Measurement (monitoring) of serum $25(\mathrm{OH}) \mathrm{D}$ is recommended after at least 3 months of supplementation with daily doses (to allow a plateau to be reached). In the case of an intermittent regimen, measurement of $25(\mathrm{OH}) \mathrm{D}$ is recommended after at least 3 months, just prior to the administration of a dose (agreement score: 4.8). It is recommended that further monitoring be performed according to physician judgment, taking into account the dose of supplementation and changes in regimen or dose (agreement score: 4.1). In addition, monitoring 25(OH)D (as well as performing a 
baseline test) can be very beneficial for compliance of the patient with supplementation. Monitoring of calcium levels is only required in patients with diseases such as primary hyperparathyroidism.

Requirements concerning $25(\mathrm{OH}) \mathrm{D}$ assays are indicated in Table 3 . The recommendation to use an assay that measures both $25(\mathrm{OH}) \mathrm{D}_{2}$ and $25(\mathrm{OH}) \mathrm{D}_{3}$ is very important in countries where vitamin $\mathrm{D}_{2}$ and vitamin $\mathrm{D}_{3}$ are both available for supplementation. In Denmark, as in several other countries, the $\mathrm{D}_{2}$ form (and not $\mathrm{D}_{3}$ ) is contained in all high dose vitamin $\mathrm{D}$ preparations available for prescription. In fact,

a reference laboratory in Denmark recently reported that, an increasing number of the tested serum samples contained significant amounts of $25(\mathrm{OH}) \mathrm{D}_{2}$, with $3 \%$ containing a concentration $>20 \mathrm{ng} / \mathrm{mL}[65] .25(\mathrm{OH}) \mathrm{D}$ is very stable in serum. A recent article reported problems with gel tubes and subsequent measurement of 25(OH)D by LC-MS/MS[66]. So, until more data are available, we recommend avoiding gel tubes.

\section{Conclusions}

The role of vitamin D in maintaining normal calcium-phosphorus homeostasis is wellestablished. Vitamin D deficiency leads to rickets in children and osteomalacia in adults, and long-term deficiency contributes to osteoporosis. More recently, vitamin D deficiency has been associated with other chronic conditions, including cardiovascular disease, autoimmune disease, and cancer. The current recommendations address vitamin D supplementation, testing and monitoring in individuals with or at risk for these diseases. Nonetheless, randomized trial data are needed to determine whether long-term supplementation with vitamin D has a favorable impact on the development or clinical course of non-skeletal diseases. 


\section{Acknowledgements}

The authors are grateful to Ismar Healthcare for their assistance in editing of the manuscript.

The Vitamin D Summit Meeting was financially supported by DiaSorin S.p.A. 


\section{References}

1. Holick MF. Vitamin D deficiency. N Engl J Med 2007;357:266-281.

2. Holick MF. Sunlight and vitamin D for bone health and prevention of autoimmune diseases, cancers, and cardiovascular disease. Am J Clin Nutr 2004;80:1678S-1688S.

3. Bischoff-Ferrari HA, Shao A, Dawson-Hughes B, Hathcock J, Giovannucci E, Willett WC. Benefit-risk assessment of vitamin D supplementation. Osteoporos Int 2009; doi:10.1007/s00198-009-1119-3:

4. Consensus study on dietary reference intakes for vitamin D and calcium. Description available online: http://www.iom.edu/Activities/Nutrition/DRIVitDCalcium.aspx [last accessed on 22/06/2010]

5. Standing Committee of European Doctors. Vitamin D nutritional policy in Europe. 2009. Available online:

http://cpme.dyndns.org:591/adopted/2009/CPME_AD_Brd_241009_179_final_EN.pdf. [last accessed on 22/06/2010]

6. Bischoff-Ferrari HA, Willett WC, Wong JB, Stuck AE, Staehelin HB, Orav EJ et al. Prevention of nonvertebral fractures with oral vitamin D and dose dependency: a metaanalysis of randomized controlled trials. Arch Intern Med 2009;169:551-561.

7. Bischoff-Ferrari HA, Dawson-Hughes B, Staehelin HB, Orav JE, Stuck AE, Theiler R et al. Fall prevention with supplemental and active forms of vitamin D: a meta-analysis of randomised controlled trials. BMJ 2009;339:b3692

8. Bischoff-Ferrari H. Vitamin D: what is an adequate vitamin D level and how much supplementation is necessary? Best Pract Res Clin Rheumatol 2009;23:789-795.

9. Jean G, Souberbielle JC, Chazot C. Monthly cholecalciferol administration in haemodialysis patients: a simple and efficient strategy for vitamin D supplementation. Nephrol Dial Transplant 2009;24:3799-3805.

10. Barreto DV, Barreto FC, Liabeuf S, Temmar M, Boitte F, Choukroun G et al. Vitamin D affects survival independently of vascular calcification in chronic kidney disease. Clin $\mathrm{J}$ Am Soc Nephrol 2009;4:1128-1135.

11. Wolf M, Shah A, Gutierrez O, Ankers E, Monroy M, Tamez H et al. Vitamin D levels and early mortality among incident hemodialysis patients. Kidney Int 2007;72:10041013.

12. London GM, Guérin AP, Verbeke FH, Pannier B, Boutouyrie P, Marchais SJ et al. Mineral metabolism and arterial functions in end-stage renal disease: potential role of 25-hydroxyvitamin D deficiency. J Am Soc Nephrol 2007;18:613-620.

13. Ravani P, Malberti F, Tripepi G, Pecchini P, Cutrupi S, Pizzini P et al. Vitamin D levels and patient outcome in chronic kidney disease. Kidney Int 2009;75:88-95.

14. Autier P, Gandini S. Vitamin D supplementation and total mortality: a meta-analysis of randomized controlled trials. Arch Intern Med 2007;167:1730-1737. 
15. Pilz S, Tomaschitz A, Drechlser C, Dekker JM, März W. Vitamin D deficiency and myocardial diseases. Mol Nutr Food Res 2010; in press:

16. Tishkoff DX, Nibbelink KA, Holmberg KH, Dandu L, Simpson RU. Functional vitamin D receptor (VDR) in the t-tubules of cardiac myocytes: VDR knockout cardiomyocyte contractility. Endocrinology 2008;149:558-564.

17. Schleithoff SS, Zittermann A, Tenderich G, Berthold HK, Stehle P, Koerfer R. Vitamin D supplementation improves cytokine profiles in patients with congestive heart failure: a double-blind, randomized, placebo-controlled trial. Am J Clin Nutr 2006;83:754-759.

18. Zittermann A, Schleithoff SS, Koerfer R. Vitamin D and vascular calcification. Curr Opin Lipidol 2007;18:41-46.

19. Sugden JA, Davies JI, Witham MD, Morris AD, Struthers AD. Vitamin D improves endothelial function in patients with Type 2 diabetes mellitus and low vitamin D levels. Diabet Med 2008;25:320-325.

20. Nagpal J, Pande JN, Bhartia A. A double-blind, randomized, placebo-controlled trial of the short-term effect of vitamin $\mathrm{D}_{3}$ supplementation on insulin sensitivity in apparently healthy, middle-aged, centrally obese men. Diabet Med 2009;26:19-27.

21. Pittas AG, Lau J, Hu FB, Dawson-Hughes B. The role of vitamin D and calcium in type 2 diabetes. A systematic review and meta-analysis. J Clin Endocrinol Metab 2007;92:2017-2029.

22. Lips P. Vitamin D deficiency and secondary hyperparathyroidism in the elderly: consequences for bone loss and fractures and therapeutic implications. Endocr Rev 2001;22:477-501.

23. Pilz S, Tomaschitz A, Ritz E, Pieber TR. Vitamin D status and arterial hypertension: a systematic review. Nat Rev Cardiol 2009;6:621-630.

24. Li YC, Kong J, Wei M, Chen ZF, Liu SQ, Cao LP. 1,25-Dihydroxyvitamin $\mathrm{D}_{3}$ is a negative endocrine regulator of the renin-angiotensin system. J Clin Invest 2002;110:229-238.

25. Pfeifer M, Begerow B, Minne HW, Nachtigall D, Hansen C. Effects of a short-term vitamin $\mathrm{D}_{3}$ and calcium supplementation on blood pressure and parathyroid hormone levels in elderly women. J Clin Endocrinol Metab 2001;86:1633-1637.

26. Margolis KL, Ray RM, Van Horn L, Manson JE, Allison MA, Black HR et al. Effect of calcium and vitamin D supplementation on blood pressure: the Women's Health Initiative Randomized Trial. Hypertension 2008;52:847-855.

27. Witham MD, Nadir MA, Struthers AD. Effect of vitamin D on blood pressure: a systematic review and meta-analysis. J Hypertens 2009;27:1948-1954.

28. Zittermann A, Frisch S, Berthold HK, Götting C, Kuhn J, Kleesiek K et al. Vitamin D supplementation enhances the beneficial effects of weight loss on cardiovascular disease risk markers. Am J Clin Nutr 2009;89:1321-1327. 
29. Giovannucci E, Liu Y, Hollis BW, Rimm EB. 25-hydroxyvitamin D and risk of myocardial infarction in men: a prospective study. Arch Intern Med 2008;168:11741180.

30. Wang TJ, Pencina MJ, Booth SL, Jacques PF, Ingelsson E, Lanier K et al. Vitamin D deficiency and risk of cardiovascular disease. Circulation 2008;117:503-511.

31. Dobnig H, Pilz S, Scharnagl H, Renner W, Seelhorst U, Wellnitz B et al. Independent association of low serum 25-hydroxyvitamin D and 1,25-dihydroxyvitamin D levels with all-cause and cardiovascular mortality. Arch Intern Med 2008;168:1340-1349.

32. Pilz S, Dobnig H, Fischer JE, Wellnitz B, Seelhorst U, Boehm BO et al. Low vitamin D levels predict stroke in patients referred to coronary angiography. Stroke 2008;39:26112613.

33. Pilz S, März W, Wellnitz B, Seelhorst U, Fahrleitner-Pammer A, Dimai HP et al. Association of vitamin D deficiency with heart failure and sudden cardiac death in a large cross-sectional study of patients referred for coronary angiography. J Clin Endocrinol Metab 2008;93:3927-3935.

34. Shoenfeld N, Amital H, Shoenfeld Y. The effect of melanism and vitamin D synthesis on the incidence of autoimmune disease. Nat Clin Pract Rheumatol 2009;5:99-105.

35. Arnson Y, Amital H, Shoenfeld Y. Vitamin D and autoimmunity: new aetiological and therapeutic considerations. Ann Rheum Dis 2007;66:1137-1142.

36. Hyppönen E, Läärä E, Reunanen A, Järvelin MR, Virtanen SM. Intake of vitamin D and risk of type 1 diabetes: a birth-cohort study. Lancet 2001;358:1500-1503.

37. Myhr KM. Vitamin D treatment in multiple sclerosis. J Neurol Sci 2009;286:104-108.

38. Pierrot-Deseilligny C. Clinical implications of a possible role of vitamin D in multiple sclerosis. J Neurol 2009;256:1468-1479.

39. Kimball SM, Ursell MR, O'Connor P, Vieth R. Safety of vitamin $\mathrm{D}_{3}$ in adults with multiple sclerosis. Am J Clin Nutr 2007;86:645-651.

40. Amital H, Szekanecz Z, Szücs G, Dankó K, Nagy E, Csépány T et al. Serum concentrations of $25-\mathrm{OH}$ vitamin $\mathrm{D}$ in patients with systemic lupus erythematosus (SLE) are inversely related to disease activity: is it time to routinely supplement patients with SLE with vitamin D? Ann Rheum Dis 2010;69:1155-1157.

41. Cutolo M, Otsa K, Uprus M, Paolino S, Seriolo B. Vitamin D in rheumatoid arthritis. Autoimmun Rev 2007;7:59-64.

42. Merlino LA, Curtis J, Mikuls TR, Cerhan JR, Criswell LA, Saag KG. Vitamin D intake is inversely associated with rheumatoid arthritis: results from the Iowa Women's Health Study. Arthritis Rheum 2004;50:72-77.

43. Fleet JC. Molecular actions of vitamin D contributing to cancer prevention. Mol Aspects Med 2008;29:388-396.

44. Tretli S, Hernes E, Berg JP, Hestvik UE, Robsahm TE. Association between serum 25(OH)D and death from prostate cancer. Br J Cancer 2009;100:450-454. 
45. Goodwin PJ, Ennis M, Pritchard KI, Koo J, Hood N. Prognostic effects of 25hydroxyvitamin D levels in early breast cancer. J Clin Oncol 2009;27:3757-3763.

46. IARC. Vitamin D and Cancer. IARC Working Group Reports Vol.5, International Agency for research on Cancer, Lyon, 25 November 2008.

47. Garland CF, Gorham ED, Mohr SB, Grant WB, Giovannucci EL, Lipkin M et al. Vitamin D and prevention of breast cancer: pooled analysis. J Steroid Biochem Mol Biol 2007;103:708-711.

48. Abbas S, Linseisen J, Slanger T, Kropp S, Mutschelknauss EJ, Flesch-Janys D et al. Serum 25-hydroxyvitamin D and risk of post-menopausal breast cancer--results of a large case-control study. Carcinogenesis 2008;29:93-99.

49. Lappe JM, Travers-Gustafson D, Davies KM, Recker RR, Heaney RP. Vitamin D and calcium supplementation reduces cancer risk: results of a randomized trial. Am J Clin Nutr 2007;85:1586-1591.

50. Chlebowski RT, Johnson KC, Kooperberg C, Pettinger M, Wactawski-Wende J, Rohan $\mathrm{T}$ et al. Calcium plus vitamin D supplementation and the risk of breast cancer. J Natl Cancer Inst 2008;100:1581-1591.

51. Wactawski-Wende J, Kotchen JM, Anderson GL, Assaf AR, Brunner RL, O'Sullivan $\mathrm{MJ}$ et al. Calcium plus vitamin D supplementation and the risk of colorectal cancer. $\mathrm{N}$ Engl J Med 2006;354:684-696.

52. Binkley N, Krueger D. Evaluation and correction of low vitamin D status. Curr Osteoporos Rep 2008;6:95-99.

53. Cavalier E, Rozet E, Gadisseur R, Carlisi A, Monge M, Chapelle JP et al. Measurement uncertainty of 25-OH vitamin D determination with different commercially available kits: impact on the clinical cut offs. Osteoporos Int 2009;doi:10.1007/s00198-009-10525:

54. KDIGO clinical practice guideline for the diagnosis, evaluation, prevention, and treatment of chronic kidney disease-mineral and bone disorder (CKD-MBD). Kidney International 2009; 76: S1-S130.

55. Barger-Lux MJ, Heaney RP. Effects of above average summer sun exposure on serum 25-hydroxyvitamin D and calcium absorption. J Clin Endocrinol Metab 2002;87:49524956.

56. Haddad JG, Chyu KJ. Competitive protein-binding radioassay for 25hydroxycholecalciferol. J Clin Endocrinol Metab 1971;33:992-995.

57. Haddock L, Corcino J, VazquesMD. 25(OH)D serum levels in the normal Puerto Rican population and in subjects with tropical sprue and parathyroid disease. P R Health Sci 1982;1:85-91.

58. Hathcock JN, Shao A, Vieth R, Heaney R. Risk assessment for vitamin D. Am J Clin Nutr 2007;85:6-18. 
59. Heaney RP. Vitamin D in health and disease. Clin J Am Soc Nephrol 2008;3:15351541.

60. Ish-Shalom S, Segal E, Salganik T, Raz B, Bromberg IL, Vieth R. Comparison of daily, weekly, and monthly vitamin D3 in ethanol dosing protocols for two months in elderly hip fracture patients. J Clin Endocrinol Metab 2008;93:3430-3435.

61. Sanders KM, Stuart AL, Williamson EJ, Simpson JA, Kotowicz MA, Young D et al. Annual high-dose oral vitamin D and falls and fractures in older women: a randomized controlled trial. JAMA 2010;303:1815-1822.

62. Holick MF, Biancuzzo RM, Chen TC, Klein EK, Young A, Bibuld D et al. Vitamin $\mathrm{D}_{2}$ is as effective as vitamin $\mathrm{D}_{3}$ in maintaining circulating concentrations of 25hydroxyvitamin D. J Clin Endocrinol Metab 2008;93:677-681.

63. Armas LAG, Hollis BW, Heaney RP. Vitamin $\mathrm{D}_{2}$ is much less effective than vitamin $\mathrm{D}_{3}$ in humans. J Clin Endocrinol Metab 2004;89:5387-5391.

64. Romagnoli E, Mascia ML, Cipriani C, Fassino V, Mazzei F, D'Erasmo E et al. Short and long-term variations in serum calciotropic hormones after a single very large dose of ergocalciferol (vitamin $\mathrm{D}_{2}$ ) or cholecalciferol (vitamin $\mathrm{D}_{3}$ ) in the elderly. J Clin Endocrinol Metab 2008;93:3015-3020.

65. Højskov CS, Heickendorff L, Møller HJ. High-throughput liquid-liquid extraction and LCMSMS assay for determination of circulating 25(OH) vitamin D3 and D2 in the routine clinical laboratory. Clin Chim Acta 2010;411:114-116.

66. Elder PA, Lewis JG, King RI, Florkowski CM. An anomalous result from gel tubes for vitamin D. Clin Chim Acta 2009;410:95

67. http://www.deqas.org/ [last accessed on 22/06/2010] 


\section{Tables}

Table 1: Overview of individuals with or at risk for musculoskeletal health problems, cardiovascular disease, autoimmune disease and cancer in whom it is recommended to measure the serum $25(\mathrm{OH}) \mathrm{D}$ level in clinical practice

\begin{tabular}{|c|c|c|c|c|c|}
\hline $\begin{array}{l}\text { Classical clinical } \\
\text { applications }\end{array}$ & $\begin{array}{l}\text { Agreement } \\
\text { score }\end{array}$ & $* *$ & $\begin{array}{l}\text { Non-classical clinical } \\
\text { applications }\end{array}$ & $\begin{array}{l}\text { Agreement } \\
\text { score }\end{array}$ & $* *$ \\
\hline $\begin{array}{l}\text { Individuals with } \\
\text { or at risk for } \\
\text { osteoporosis }\end{array}$ & 5.0 & 23 & Cardiology & & \\
\hline $\begin{array}{l}\text { Elderly subjects } \\
\text { with a recent fall } \\
\text { accident }\end{array}$ & 5.0 & 23 & $\begin{array}{l}\text { All individuals } \\
\text { with hypertension }\end{array}$ & 4.2 & 21 \\
\hline Pregnant women & 4.7 & 22 & Autoimmunity & & \\
\hline $\begin{array}{l}\text { Patients with } \\
\text { chronic kidney } \\
\text { disease (CKD) 4- } \\
\text { 5D }\end{array}$ & 4.9 & 23 & $\begin{array}{l}\text { Patients with } \\
\text { autoimmune } \\
\text { disease }\end{array}$ & 4.6 & 22 \\
\hline $\begin{array}{l}\text { Transplant } \\
\text { patients }\end{array}$ & 4.7 & 23 & $\begin{array}{l}\text { Subjects at high } \\
\text { risk for } \\
\text { autoimmune } \\
\text { disease }\end{array}$ & 4.3 & 22 \\
\hline $\begin{array}{l}\text { Patients with } \\
\text { conditions or } \\
\text { treatments that } \\
\text { can lead to bone } \\
\text { loss }\end{array}$ & 5.0 & 22 & $\begin{array}{l}\text { Patients starting or } \\
\text { already on } \\
\text { corticosteroids }\end{array}$ & 4.8 & 20 \\
\hline Obese individuals & 4.3 & 20 & Oncology & & \\
\hline $\begin{array}{l}\text { Patients with } \\
\text { diabetes }\end{array}$ & 4.4 & 21 & $\begin{array}{l}\text { All cancer } \\
\text { patients } \\
\text { undergoing } \\
\text { treatment* }\end{array}$ & 4.7 & 21 \\
\hline $\begin{array}{l}\text { Hospitalized } \\
\text { patients }\end{array}$ & 4.4 & 22 & & & \\
\hline $\begin{array}{l}\text { Patients with } \\
\text { bone/muscle pain } \\
\text { or aches }\end{array}$ & 4.7 & 24 & & & \\
\hline
\end{tabular}


* Emphasis on premenopausal women with early breast cancer receiving adjuvant chemotherapy or gonadotropin-releasing hormone $(\mathrm{GnRH})$ analogs, on breast cancer patients under anti-aromatase therapy and on prostate cancer patients under hormone ablative treatment is warranted because of the negative influence of the treatment on bone health

** Number of authors that gave a score; the authors only expressed their agreement for the disease areas they were familiar with. 
Table 2: Serum25(OH)D range (ng/mL) according to the authors

\begin{tabular}{|l|c|}
\hline Proposed 25(OH)D range & Number of experts \\
\hline $30-100$ & 20 \\
\hline $30-150$ & 1 \\
\hline $30-80$ & 1 \\
\hline $30-50$ & 2 \\
\hline $40-100$ & 1 \\
\hline
\end{tabular}

Table 3: Requirements for $25(\mathrm{OH}) \mathrm{D}$ assays

\begin{tabular}{|l|}
\hline Requirements for $25(\mathrm{OH}) \mathrm{D}$ assays \\
\hline Choose an assay that measures both $25(\mathrm{OH}) \mathrm{D}_{2}$ and $25(\mathrm{OH}) \mathrm{D}_{3}$ \\
\hline If using an assay that separates $25(\mathrm{OH}) \mathrm{D}_{2}$ and $25(\mathrm{OH}) \mathrm{D}_{3}$ (i.e. HPLC or LC/MS-MS) \\
indicate the sum of the 2 compounds $\left(25(\mathrm{OH}) \mathrm{D}_{2}+25(\mathrm{OH}) \mathrm{D}_{3}\right)$ as the main results in \\
your results sheet \\
\hline Participate to an external quality control scheme that provides materials with a \\
documented commutability with human sera (e.g. the UK based DEQAS) [67] \\
\hline An internal quality control program has to be carried out in every laboratory by using \\
different levels samples and valuable criteria for rejecting or accepting "the analytical \\
run" \\
\hline Do not use population-based reference values (i.e. the concentrations of an apparently \\
are available \\
healthy population) in addition to a recommended range for $25(\mathrm{OH}) \mathrm{D}$. This is highly \\
confusing for the clinician
\end{tabular}


Appendix 1: Table on individual position of the 25 participants regarding the serum $25(\mathrm{OH}) \mathrm{D}$ range

\begin{tabular}{|c|c|}
\hline Participants & Proposed 25(OH)D range $(\mathrm{ng} / \mathrm{mL})$ \\
\hline \multicolumn{2}{|l|}{ Classical application group } \\
\hline Heike A. Bischoff-Ferrari & $30-100$ \\
\hline Jean-Jacques Body (co-chair) & $30-100$ \\
\hline Etienne Cavalier & $30-100$ \\
\hline Peter R. Ebeling & $30-50$ \\
\hline Patrice Fardellone & $30-100$ \\
\hline Lene Heickendorff & $30-100$ \\
\hline Bruce W. Hollis & $40-100$ \\
\hline Sofia Ish-Shalom & $30-100$ \\
\hline Guillaume Jean & $30-50$ \\
\hline Alvaro Largura & $30-150$ \\
\hline Mario Plebani (general chair of the meeting) & $30-100$ \\
\hline Jean-Claude Souberbielle (co-chair) & $30-100$ \\
\hline Andre Valcour & $30-100$ \\
\hline \multicolumn{2}{|l|}{ Oncology group } \\
\hline Sara Gandini & $30-100$ \\
\hline Joan M. Lappe (chair) & $30-100$ \\
\hline \multicolumn{2}{|l|}{ Cardiology group } \\
\hline Damien Gruson & $30-100$ \\
\hline Alain P. Guérin & $30-100$ \\
\hline Stefan Pilz & $30-100$ \\
\hline Thomas J. Wang (chair) & $30-100$ \\
\hline Armin Zittermann & $30-80$ \\
\hline \multicolumn{2}{|l|}{ Autoimmunity group } \\
\hline Philipp von Landenberg & $30-100$ \\
\hline Tomas Olsson & $30-100$ \\
\hline Charles Pierrot-Deseilligny & $30-100$ \\
\hline Yehuda Shoenfeld (chair) & $30-100$ \\
\hline Angela Tincani & $30-100$ \\
\hline
\end{tabular}

